\section{Specific determination of plasma and urinary lactose}

\author{
P. A. TOSELAND From the Department of \\ Chemical Pathology, The Children's Hospital, \\ Sheffield.
}

The recognition of three cases of lactose intolerance in the Sheffield Children's Hospital led to an investigation into the specific determination of plasma and urinary lactose levels following lactose loading tests.

Using the method of Reithel (1962) (see below) it was found that aqueous solutions of lactose $(0.1 \mathrm{ml}$.) were readily and consistently determined even at levels down to $5 \mathrm{mg}$. per $100 \mathrm{ml}$.

As plasma glucose interferes with the determination it was destroyed by glucose oxidase and the oxidase itself was removed during the subsequent deproteinization.

\section{DETERMINATION}

The method depends upon the measurement of glucose liberated from lactose by hydrolysis with $\beta$-galactosidase, by the following steps:-

1 Lactose $\rightarrow$ glucose + galactose. With a comparatively high concentration of hexokinase and adenosine triphosphate, the glucose is immediately converted to glucose-6-phosphate, as in step 2.

2 Glucose + A.T.P. $\rightarrow$ glucose-6-phosphate + A.D.P. The glucose-6-phosphate produced is oxidized by glucose6-phosphate dehydrogenase in the presence of nicotinamide-adenine dinucleotide phosphate (N.A.D.P.).

3 Glucose-6-phosphate $\rightarrow 6$-phosphogluconate + N.A.D.P.H. $+\mathrm{H}^{+}$.

The increase in the amount of N.A.D.P.H. measured by the increase in optical density at $340 \mathrm{~m} \mu$ is directly proportional to the amount of glucose liberated from the original lactose.

In Reithel's method, reaction 1 is made rate-limiting in order to resist the transglucosidase activity of the enzyme,

Received for publication 20 April 1967

Rapid method for the estimation of plasma haemoglobin levels-concluded.

I should like to thank Dr. J. C. B. Fenton, at whose suggestion this work was initiated, for his advice and criticism, and Dr. A. B. Anderson for his encouragement.

\section{REFERENCES}

Allen, W. M. (1950). J. clin. Endocr., 10, 71.

Dacie, J. V., and Lewis, S. M. (1963a). Practical Haematology. 3rd ed., p. 36. Churchill, London.

, L. (1963b). Ibid., 3rd ed., p. 380. Churchill, London.

Rimington, C., and Sveinsson, S. L. (1950). Scand. J. clin. Lab. Invest. 2. 209. $\beta$-galactosidase. Plasma that has been either frozen or freshly obtained is mixed with an equal quantity of glucose oxidase reagent containing catalase. The latter reagent is included in order to give rapid decomposition of the hydrogen peroxide produced by the oxidase, because a previous series of unsatisfactory results was attributed to hydrogen peroxide or other peroxides interfering with the dehydrogenase enzyme.

The buffering capacity of the plasma is sufficient to ensure complete removal of plasma glucose by the oxidase reagent.

\section{METHOD}

REAGENTS 1 Salt solution. Potassium chloride and magnesium chloride: $20 \mathrm{~g} . \mathrm{MgCl}_{2} \cdot 6 \mathrm{H}_{2} \mathrm{O}$ and $7.5 \mathrm{~g} . \mathrm{KCl}$ per $100 \mathrm{ml}$. of deionized water.

2 Adenosine triphosphate ${ }^{1}$ (A.T.P.): $20 \mathrm{mg}$. per $\mathrm{ml}$ in deionized water.

3 Nicotine-adenine-dinucleotide phosphate ${ }^{1}$ (N.A.D.P.):

$20 \mathrm{mg}$. per $\mathrm{ml}$. in deionized water.

4 Hexokinase $^{1}$ : $10 \mathrm{mg}$. per ml.

5 Glucose-6-phosphate dehydrogenase ${ }^{1}: 5 \mathrm{mg}$. per $\mathrm{ml}$

$6 \beta$-Galactosidase ${ }^{2}$ : $20 \mathrm{mg}$. per. $\mathrm{ml}$. in deionized water.

7 'Tris' 2-amino -2- (hydroxymethyl) 3-propane-1:3diol: $0.5 \%$ solution in deionized water.

8 Glucose oxidase reagent: 9 parts of Fermcozyme 1 part catalase ${ }^{4}$ solution.

Fresh heparinized plasma should be used immediately or stored below $0^{\circ} \mathrm{C}$. The plasma $(0.05 \mathrm{ml}$.) is mixed with an equal quantity of glucose oxidase reagent in a micro-tube $(0.4 \mathrm{ml}$. polypropylene) and incubated at $56^{\circ} \mathrm{C}$ for 20 minutes, thereafter $0.05 \mathrm{~N}$ acetic acid $(0.1 \mathrm{ml}$. is added and the contents are mixed on a vibrator.

Deproteinization is completed by heating the tuhes in a water bath at $70^{\circ} \mathrm{C}$ for three minutes and then cooling rapidly. After centrifugation $0.12 \mathrm{ml}$. of the supernatant is transferred to a $0.5 \mathrm{ml}$. microcell in a spectrophotometer, reading at $340 \mathrm{~m} \mu$ (we have used the Optica instrument). An equal volume of $0.5 \%$ Tris solution is added and the contents shaken, giving a final $p \mathrm{H}$ of 7.4. The following solutions are then added to the cell in the stated order.
(i) Salt solution
(ii) N.A.D.P. .
(iii) A.T.P.
(iv) Hexokinase
(v) G-6P.D.
5 microlitres 10 microlitres 10 microlitres 5 microlitres 10 microlitres

the cell volume is made up with deionised water.

The cell contents are thoroughly mixed and the absorbance is read at $340 \mathrm{~m} \mu$. If the reading is not steady it should be allowed to become so before the optical density is noted. At this point the absorbance at $400 \mathrm{~m} \mu$. is also taken.

$\beta$-Galactosidase solution, 20 microlitres, is added and the absorbance at $340 \mathrm{~m} \mu$ is allowed to become steady before reading; once it has done so a reading at $400 \mathrm{~m} \mu$

${ }^{1}$ C. F. Boehringer and Sohne

$2 \beta$-galactosidase Lactase $F$ from British Drug Houses.

${ }^{3}$ Hughes and Hughes.

- Sigma Chemical Co. 
is made. This latter reading will normally show an increase and this value must be subtracted from the increase in optical density at $340 \mathrm{~m} \mu$. The background absorbance is undoubtedly due to the high concentration of protein in the semi-micro cell.

The lactose content of the sample is directly proportional to the optical density difference between the readings at $340 \mathrm{~m} \mu$ minus any increase at $400 \mathrm{~m} \mu$.

Each determination should be performed in duplicate, as well as the blanks; in a lactose tolerance test the fasting specimen is ideally treated as the blank determination. Standards must be prepared by adding small amounts of aqueous lactose solutions to plasma. Purely aqueous standards do not have the same ultimate $p \mathrm{H}$, no doubt due to the removal of hydrogen ions by protein, in the protein-precipitation step.

\section{CALCULATION}

A standard solution of $20 \mathrm{mg}$. per $100 \mathrm{ml}$. is made by diluting a $200 \mathrm{mg}$. per $100 \mathrm{ml}$. standard with pooled plasma. If S340 is the increase in optical density of standard at $340 \mathrm{~m} \mu$ and S400 is the increase in optical density of standard at $400 \mathrm{~m} \mu$ and $\mathrm{T} 340$ is the increase in optical density of test at $340 \mathrm{~m} \mu$ and T400 is the increase in optical density of test at $400 \mathrm{~m} \mu$ the lactose concentration in the original sample in $\mathrm{mg}$. per $100 \mathrm{ml}$.

$$
=\frac{\mathrm{T} 340-\mathrm{T} 400}{\mathrm{~S} 340-\mathrm{S} 400} \times 20
$$

A calibration curve has been shown to be linear up to $35 \mu \mathrm{g}$. of lactose in a $0.5 \mathrm{ml}$. cell (i.e. with an aliquot of 120 microlitres, linearity is maintained up to $120 \mathrm{mg}$. per $100 \mathrm{ml}$. in the original plasma). The optical density per $5 \mu \mathrm{g}$. of lactose is approximately 0.1 using a cell of capacity $0.5 \mathrm{ml}$. and optical path-length of $1 \mathrm{~cm}$. Such a particular cell size is important for economy of reagents which are expensive.

\section{URINE SAMPLES}

Urine samples should be treated in the same manner as plasma; samples giving results greater than $100 \mathrm{mg}$. per $100 \mathrm{ml}$. should be diluted 1:2. Values greater than this are well beyond the linearity of the method.

\section{COMMENT}

A method is presented for the measurement of plasma and urine lactose. Significant amounts of lactose were detected only in plasma following lactose loads. These were used to provide a more accurate differentiation of lactose intolerance, alactasia, and lactosuria.

Several of the infants with lactose intolerance and lactosuria had plasma lactose levels from 14 to $22 \mathrm{mg}$. per $100 \mathrm{ml}$., with a mean value of $19 \mathrm{mg}$. per $100 \mathrm{ml}$. These levels were detected in the range $60-90$ minutes after ingestion of the lactose. Normal levels did not rise above $5 \mathrm{mg}$ per $100 \mathrm{ml}$.

The author wishes to thank Dr. A. Jordan and Dr. J. Liddell for their advice and helpful suggestions.

\section{REFERENCE}

Reithel, F. J. (1962). In Methods of Enzymatic Analysis, p. 103. Springer, Berlin, and Academic Press, New York and London.

\section{A simple device for microdialysis}

\section{A. A. CODD, From the Public Health Laboratory, General Hospital, Newcastle upon Tyne}

One of the problems of analysing macromolecular substances by immunodiffusion and immunoelectrophoretic techniques is that of concentrating these substances from the dilute fractions obtained off columns of ion-exchange and gel-filtration materials, or eluates of substances adsorbed to cells. The difficulty is increased when only small volumes of the starting material are available or required for analysis. Loss of material is considerable when small volumes are concentrated in cellophane bags by dialysis against polyethylene glycol. Much of it remains trapped in the folds around the occluding knots. Some of the difficulty can be avoided by the use of the simple device described.
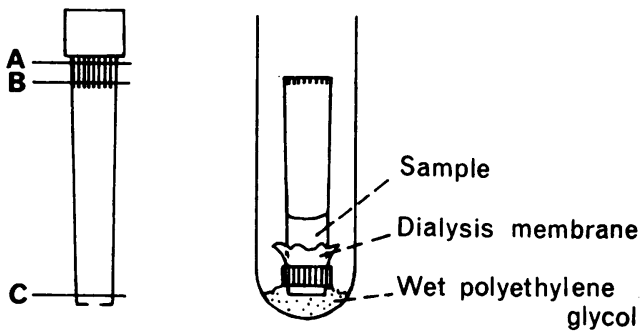

The wide end of a conical plastic needle cover is cut off squarely (A). A $3 \mathrm{~mm}$. ring is cut from this end (AB) and slid over the narrow end which is then cut off below the ring (C). The sharp outer edge of the narrow end of the tube is made smooth. A small square of dialysis membrane is applied to the narrow end of the tube and secured by means of the ring as illustrated. The sample to be concentrated is pippetted into the tube which is transferred to a $1 \times 5 \mathrm{~cm}$. tube containing a small quantity of wet polyethylene glycol. Within a few hours a sample volume of $0.1 \mathrm{ml}$. is concentrated tenfold. The concentrate may be removed with a fine pipette and applied directly to the well or origin of the system being used in the analysis. Alternatively, for some procedures it is convenient to leave the sample in the tube until all the water has dialysed into the polyethylene glycol. The high molecular weight material deposits as a uniform circular film on the membrane. After washing the outside of the device, to remove the polyethylene glycol, a sinall disc, with the deposit on it, is cut from the membrane with a sharp cork-borer. The disc may be applied, deposit side down, to an agar surface in an immunological system. In this way a large number of samples may be examined easily, and, as very little material is lost, a reasonable quantitative assessment can be made of a particular immunologically precipitating constituent. This

Received for publication 15 May 1967. 